\title{
Effectiveness of Selected Microbial Strains on the Growth of Sweet Sorghum
}

\author{
Arturo Díaz-Franco1, Oscar Arath Grageda-Cabrera², \\ Mónica Guadalupe Lozano-Contreras ${ }^{3 *}$ \\ ${ }^{1}$ Instituto Nacional de Investigaciones Forestales, Agricolas y Pecuarias (INIFAP), Campo Experimental Rio Bravo \\ Km 61 Carretera Matamoros-Reynosa, Rio Bravo, Tamaulipas, Mexico \\ ${ }^{2}$ Instituto Nacional de Investigaciones Forestales, Agricolas y Pecuarias (INIFAP), Campo Experimental Bajio Km \\ 6.5 Carretera Celaya-San Miguel de Allende, Celaya, Guanajuato, Mexico \\ ${ }^{3}$ Instituto Nacional de Investigaciones Forestales, Agricolas y Pecuarias (INIFAP), Campo Experimental Mococha, \\ Km 25 Carretera Merida-Motul, Yucatan, Mexico \\ Email: ${ }^{*}$ lozano.monica@inifap.gob.mx
}

Received 3 July 2015; accepted 4 August 2015; published 7 August 2015

Copyright (C) 2015 by authors and Scientific Research Publishing Inc.

This work is licensed under the Creative Commons Attribution International License (CC BY).

http://creativecommons.org/licenses/by/4.0/

(c) (i) Open Access

\begin{abstract}
Microbial inoculants are of great importance in agro-ecology and plants. However, the symbiotic effectiveness of strains may vary between species or within the same species. Aim of the study was to select experimental microbial strains of national origin, to know its impact on growth of sweet sorghum (Sorghum bicolor) in greenhouse and sterile soil. Five strains of arbuscular mycorrhizal fungi (AMF) and eight rhizobacteria (two of them mutagenized) were compared with non-inoculated plants as control. Variables measured were index of chlorophyll SPAD, plant height, stem diameter (from the middle section), fresh biomass from stem, leaf, panicle, radical, and stem sugars content ( ${ }^{\circ}$ Brix) of every two internodes. The results showed that in the majority of cases, microbial strains exceeded the values of variables compared with control plants. The highest values of chlorophyll (41.8 SPAD), stem diameter (13.5 mm) and total fresh biomass (144.3 g), were recorded with rhizobacterias BS410 (Herbaspirillum sp.), B2709 (Pseudomonas sp.) and B4M4 (Azospirillum sp.), respectively.
\end{abstract}

\section{Keywords}

Beneficial Microorganisms, Sorghum bicolor, Greenhouse Conditions

\footnotetext{
${ }^{*}$ Corresponding author.
}

How to cite this paper: Díaz-Franco, A., Grageda-Cabrera, O.A. and Lozano-Contreras, M.G. (2015) Effectiveness of Selected Microbial Strains on the Growth of Sweet Sorghum. Agricultural Sciences, 6, 772-777. 


\section{Introduction}

Microbial inoculants or bio-fertilizers, based on arbuscular mycorrhizal fungi (AMF) and plant growth promoting bacteria (PGPR), currently have great ecological and economic importance in agriculture. The preparation of microbial inoculants effectively is of great importance such as biotechnology in agriculture, although particularly those with economic viability. Within the symbiotic activity, AMF manifest different mechanisms that induce a further exploration of soil through the hyphae, decrease the effects of abiotic conditions for plant, produce plant hormones that stimulate the growth, facilitate the absorption of nutrients, produce glomalin that adhere soil particles, and induce protective action against some plant pathogens of soil [1] [2]. The positive effect of rhizosphere bacteria colonizing in grasses, based on its production of plant growth stimulating substances, has been demonstrated by different authors [3] [4]. The group of PGPR can stimulate the plants through production of phytohormones, nitrogen, or biocontrol of plant pathogens using antifungals such as siderophores or lytic enzymes compounds [5] [6].

It is important to identify microorganisms with potential to be used within agricultural systems through isolation and identification procedures [7] [8]. However, some strains of micro-organisms benefit in greater degree to a specific host compared with others, in addition its functionality can be altered under particular conditions, a fact which shows the marked differences between species and even between strains of the same species [4] [9] [10]. Many inoculants are prepared from microbial strains introduced or foreign, but now has been given emphasis on the use of native strains, which can be reintroduced through inoculation to crops, with greater capacity for adaptation and effectiveness in specific climates and sites [2] [4] [11] [12].

Sweet sorghum (Sorghum bicolor) is a crop used in the production of refined sugar, alcohol, biofuel, among others [13] [14]. This sort of grass is particularly important since it shows comparative advantages over other crops. C4 photosynthesis, tolerant to drought, rapid growth, accumulates large amounts of sugars fermentable in the stem and biomass, has wide adaptability and tolerates adverse conditions of production, and feasible it's planting in areas that are not appropriate for different crops [15] [16]. It is important to note that the use of biofuels produces clean, efficient energy [17] [18]. Thus, the objective of the study was to select experimental microbial strains of national origin, to know its impact on the growth of sorghum sweet under greenhouse conditions.

\section{Materials and Methods}

\subsection{Experimental Conditions}

The study was conducted in a greenhouse of low-technology $\left(19^{\circ} \mathrm{C}-31^{\circ} \mathrm{C}\right)$ at Rio Bravo Experimental Station, INIFAP, Rio Bravo, Tamaulipas ( $25^{\circ} 57^{\prime} \mathrm{N} 98^{\circ} 01^{\prime} \mathrm{W}$; 25 mosl). The soil used was mixed with $10 \%$ (v/v) of Termolita $^{\circledR}$, and deposited on plastic canvas, coated with the same, and sterilized with methyl bromide; 9 kg capacity plastic bags were filled after five days. The soil characteristics were: $\mathrm{MO}, 1.4 \% ; \mathrm{pH}, 8.0 ; \mathrm{CE}, 1.1\left(\mathrm{dSm}^{-1}\right) ; \mathrm{N}$, $\mathrm{P}, \mathrm{K}, 13.7,22$ and $907 \mathrm{mg} \cdot \mathrm{kg}^{-1}$, respectively; and sandy loam texture [19].

\subsection{Microbial Strains}

Experimental microorganism strains from INIFAP were used [20]. AMF strains were 35 (Glomus mossae) (M35), 20 (Gigaspora albida) (M20) and 3 (G. mossae) (M3) from General Teran Experimental Station, INIFAP; rhizobacteria were Azospirillum sp. mutagenized (B4M2), Pseudomonas sp. (BPSON), Azospirillum sp. mutagenized (B4M4), Herbaspirillum sp. (BH and BS410), Ranhella aquatilis (BRA), Azospirillum sp. (BAZO) and Pseudomonas sp. (B2709), obtained from the Bajio Experimental Station, INIFAP; as control were mycorrhiza INIFAP (Rhizophagus intraradices) (M) and absolute, non-inoculated plants. The inoculum of AMF was $\geq 60$ spores $\mathrm{g}^{-1}$ of soil and rhizobacteria with a concentration of $10^{7}-10^{8} \mathrm{UFC}^{-1}$ in peat.

\subsection{Experimental Management}

Soil inoculation was made at rate of 2 and $4 \mathrm{~g}$ of bacterial and mycorrhizal inoculum, respectively, per bag, and at a depth of $10-11 \mathrm{~cm}$. The inoculum was covered with a layer of soil of $\approx 5 \mathrm{~cm}$. Sowing was on February 17 2012; sweet sorghum hybrid seeds "Dale" were disinfected with a solution of sodium hypochlorite at $10 \%$ for 10 min and were planted five seeds in each bag to leave a seedling. Each treatment was repeated 10 times in a com- 
pletely randomized design. Plants were irrigated regularly and kept for three months. The variables evaluated in the milky-dough grain stage were: determination of the content of foliar chlorophyll in the upper part of the plant, with a detector of chlorophyll Minolta SPAD-502 ${ }^{\circledR}$, the average of three readings during the development of the crop; at the end of the experiment (May 18) was registered plant height, stem diameter (in the middle), biomass from fresh stem (g. plant ${ }^{-1}$ ), leaves, panicle and radical, and content of sugars through ${ }^{\circ}$ Brix, obtained with refractometer, from the average of readings in every two internodes of the stem $(2,4,6)[13]$. Data were processed by analysis of variance and the differences between means were by Tukey ( $\leq 0.05)$. In addition, between variables correlations were made through the analysis of Pearson $(\mathrm{p} \leq 0.05)$.

\section{Results and Discusion}

The results showed that all measured variables, manifested symbiotic effect of inoculated microbial strains and who in most cases exceeded the values of control plants (Table 1). For plant characteristics, strain BS410 was which stand out on content of chlorophyll with 41.8 SPAD. The increase in photosynthetic pigments could be related to the increase in the contribution of $\mathrm{N}$ to the plant by the symbiotic activity [3] [21]. BPSON, B4M4 and BS410 obtained greater plant height with more than $152 \mathrm{~cm}$; the higher stem diameter was registered with B2709 (13.5 mm).

Results could be explained by the effect of different hormones secreted by these strains with a direct influence on the development of these variables. It was reported by Vessey, 2003, as well as by Matiru and Dakora, 2004 [22] that the indole acetic acid produced by rhizobacteria can cause root initiation and cell elongation; the production of cytokinins can promote cell division and expansion of tissues; as well as gibberellins that influence the elongation of stem.

For the concentration of sugars in the stem ( ${ }^{\circ}$ Brix), most of the strains overcome control plants $(\mathrm{p}=0.001)$ (Table 1). There is not background information on the influence of microbial inoculants in sweet sorghum production. However, results with sugar cane (Saccharum officinarum) [23], showed that different strains of PGPR manifested variable response for plant height, stem diameter and sugars production. In the present study the expression of ${ }^{\circ}$ Brix was independent to the rest of the measured variables since there was no correlation with these.

Table 1. Influence of microbial strains of arbuscular mycorrhizal fungi and rhizobacteria, on characteristics of sweet sorghum plant.

\begin{tabular}{|c|c|c|c|c|}
\hline \multirow[t]{2}{*}{ Strain } & \multicolumn{4}{|c|}{ Plant characteristics } \\
\hline & $\mathrm{SPAD}^{\S}$ & Plant height (cm) & Stem diameter (mm) & ${ }^{\circ} \mathrm{Brix}^{\S \S}$ \\
\hline M35 & $39.7 a b^{* *}$ & $147.5 \mathrm{abc}$ & $12.3 \mathrm{ab}$ & $9.1 \mathrm{ab}$ \\
\hline M20 & $39.6 \mathrm{ab}$ & $147.0 \mathrm{abc}$ & $12.7 \mathrm{ab}$ & $9.3 \mathrm{ab}$ \\
\hline M3 & $39.4 \mathrm{ab}$ & $150.7 \mathrm{ab}$ & $12.3 \mathrm{ab}$ & $9.4 \mathrm{ab}$ \\
\hline B4M2 & 37.1 bcd & $146.5 \mathrm{abc}$ & $12.9 \mathrm{ab}$ & $10.4 \mathrm{a}$ \\
\hline BPSON & $40.5 \mathrm{ab}$ & $152.4 \mathrm{a}$ & $12.5 \mathrm{ab}$ & 9.7 a \\
\hline B4M4 & $39.4 \mathrm{ab}$ & 154.7 a & $12.8 \mathrm{ab}$ & $10.1 \mathrm{a}$ \\
\hline $\mathrm{BH}$ & 37.7 abc & 134.9 cde & 11.5 bc & 9.6 a \\
\hline BS410 & $41.8 \mathrm{a}$ & 154.9 a & $12.2 \mathrm{ab}$ & $10.3 \mathrm{a}$ \\
\hline BRA & $39.5 \mathrm{ab}$ & 136.3 cde & $10.8 \mathrm{c}$ & $9.7 \mathrm{a}$ \\
\hline BAZO & $34.0 \mathrm{~d}$ & 137.6 bcd & $10.8 \mathrm{c}$ & $10.1 \mathrm{a}$ \\
\hline B2709 & $33.9 \mathrm{~d}$ & 136.0 cde & $13.5 \mathrm{a}$ & 9.9 a \\
\hline M & $38.2 \mathrm{abc}$ & 129.0 de & $12.3 \mathrm{ab}$ & $9.7 \mathrm{a}$ \\
\hline Test & $36.6 \mathrm{~cd}$ & 123.9 e & $10.7 \mathrm{c}$ & $7.6 \mathrm{~b}$ \\
\hline$P>F$ & 0.008 & 0.001 & 0.001 & 0.001 \\
\hline
\end{tabular}

\footnotetext{
${ }^{\S}$ Average of three readings. ${ }^{\S \S}$ Average of three internodes. ${ }^{*}$ Distinct letters in the row indicate significant differences according to Tukey’s test (p $\leq$
} $0.05)$. 
In the case of the characteristics of biomass weight, all variables were significantly influenced by the inoculated strains. The most outstanding strains to stem biomass were the mutagenized B4M2 and B4M4, with 66.1 and $66.2 \mathrm{~g}$, respectively; in leaves also stand out the strain B4M4 (53.9 g); in panicle, the strains with higher value were M35 (30.3 g) and BSON (27.3 g); however, for the variable total aerial biomass the strain that most impacted on productivity was B4M4 with $144.3 \mathrm{~g}, 51 \%$ higher than control plants. Total aerial biomass correlated with the biomass of stem $(r=0.955)$, leaves $(r=0.746)$ and panicle $(r=0.874)$. Similarly, it was reported [21] increases of $24 \%$ in aerial biomass of wheat (Triticum aestivum) when it was inoculated with Azospirillum zeae and Sinorhizobium meliloti strains under controlled conditions. Likewise, variations of $16 \%$ to $24 \%$ were reported [24] in the increase of maize foliar biomass with four species of AMF.

Radical biomass was increased $(\mathrm{p}=0.001)$ by seven of the 12 evaluated microbial strains (Table 2$)$. This feature could reflect a greater capacity of absorption of nutrients, which becomes the main factor for plant growth. This can be explained with correlation manifested between the aerial and radical biomass $(r=0.830)$. It was described [21] that inoculants application, simple or combined, were able to influence the development of aerial biomass, from the development of root system. Results in wheat [25] showed increased of radical development, root length and number of lateral roots in wheat, variables that were correlated with the strains of $A$. brasilense more efficient in the production of phytohormones.

In summary, under the conditions of this study, it was observed increase the values of different variables measured in the plant as effects of microbial strains symbiosis. In particular, the concentration of sugars in the stem ( ${ }^{\circ}$ Brix) and the total aerial biomass are the characteristics related to productivity of sweet sorghum. In other related studies [4] [24] [26], it has emphasized the need to select efficient PGPR and AMF strains to increase growth and productivity of crops. The practice of microbial inoculation, besides being economical and ecologically beneficent, could be part of sustainable agriculture systems.

\section{Conclusions}

Microbial strains were able to increase values of the different variables measured in sweet sorghum. In particular, the sugar content in stem and total biomass are related to crop productivity. The results indicated that in most

Table 2. Influence of microbial strains of arbuscular mycorrhizal fungi and rhizobacteria, on sweet sorghum plant biomass.

\begin{tabular}{|c|c|c|c|c|c|}
\hline \multirow[t]{2}{*}{ Strain } & \multicolumn{5}{|c|}{ Biomass (g) } \\
\hline & Stem & Leaves & Panicle & Total aerial & Radical \\
\hline M35 & 53.9 bc $^{*}$ & $51.3 \mathrm{abc}$ & $30.3 \mathrm{a}$ & 135.5 abc & $23.6 \mathrm{a}$ \\
\hline M20 & $61.3 \mathrm{ab}$ & $50.3 \mathrm{abc}$ & 23.0 bcd & 134.5 abc & 26.3 a \\
\hline M3 & $61.4 \mathrm{ab}$ & $51.5 \mathrm{ab}$ & 20.2 de & 133.1 abcd & 26.0 a \\
\hline B4M2 & $66.2 \mathrm{a}$ & 45.4 cdef & $25.0 \mathrm{ab}$ & $136.5 \mathrm{ab}$ & $28.6 \mathrm{a}$ \\
\hline BPSON & $62.7 \mathrm{ab}$ & 49.1 abcd & $27.3 \mathrm{a}$ & $139.0 \mathrm{ab}$ & 26.6 a \\
\hline B4M4 & $66.1 \mathrm{a}$ & 53.9 a & 24.4 abc & $144.3 \mathrm{a}$ & $25.2 \mathrm{a}$ \\
\hline $\mathrm{BH}$ & $46.3 \mathrm{~cd}$ & $42.7 \mathrm{f}$ & 15.8 ef & $104.7 \mathrm{e}$ & $16.2 \mathrm{~b}$ \\
\hline BS410 & $60.7 \mathrm{ab}$ & 49.2 abcde & 20.3 cde & 130.0 abcd & $16.6 \mathrm{~b}$ \\
\hline BRA & $47.0 \mathrm{~cd}$ & 47.1 bcde & 17.1 def & 111.1 de & $13.4 \mathrm{~b}$ \\
\hline BAZO & $41.7 \mathrm{~d}$ & $39.5 \mathrm{f}$ & $13.4 \mathrm{f}$ & $94.6 \mathrm{e}$ & $13.2 \mathrm{~b}$ \\
\hline B2709 & $50.0 \mathrm{~cd}$ & $51.7 \mathrm{ab}$ & 14.9 ef & 116.6 bcde & $12.9 \mathrm{~b}$ \\
\hline M & $49.3 \mathrm{~cd}$ & 51.0 abc & $13.7 \mathrm{f}$ & 114.0 cde & $22.6 \mathrm{a}$ \\
\hline Test & $40.2 \mathrm{~d}$ & $43.0 \mathrm{f}$ & $12.4 \mathrm{f}$ & $95.6 \mathrm{e}$ & $13.3 \mathrm{~b}$ \\
\hline$P>F$ & 0.001 & 0.002 & 0.005 & 0.001 & 0.001 \\
\hline
\end{tabular}

${ }^{*}$ Distinct letters in the row indicate significant differences according to Tukey’s test $(\mathrm{p} \leq 0.05)$. 
cases, the microbial strains exceeded the values of variables obtained by control plants. Most of the strains increased significantly sugar content, average $9.94{ }^{\circ}$ Brix, compared with non-inoculated plants $\left(7.6{ }^{\circ} \mathrm{Brix}\right)$. The highest values of chlorophyll (41.8 SPAD), stem diameter $(13.5 \mathrm{~mm})$ and total fresh biomass (144.3 g), were recorded with rhizobacterias BS410 (Herbaspirillum sp.), B2709 (Pseudomonas sp.) and B4M4 (Azospirillum sp.), respectively.

\section{Acknowledgements}

The support received by SAGARPA through the project "Research in bio-fertilizers and organic amendments" is grateful for. Also thanks to Mr. Juan Olvera Martinez who supported field activities.

\section{References}

[1] Smith, G.S. and Read, D.J. (2008) Mycorrhizal Symbiosis. 3rd Edition, Academic Press, London, 750 p.

[2] Ferrera, C.R. and Alarcón, A. (2008) Biotecnología de hongos micorrízicos arbusculares. In: Díaz, F.A. and Mayek, P.N., Eds., La Bofertilización como Tecnología Sostenible, Plaza y Valdés, CONACYT, Mexico, 25-38.

[3] Askary, M., Mostajeran, A., Amoaghaei, R. and Mostajeran, M. (2009) Influence of the Co-Inoculation Azospirillum brasilense and Rhizobium meliloti plus 2,4-D on Grain Yield and N, P, K Content of Triticum aestivum. AmericanEurasian Journal of Agricultural \& Environmental Sciences, 5, 296-307. http://www.idosi.org/aejaes/jaes5\%283\%29/1.pdf

[4] Hungria, M., Campo, R.J., Souza, E.M. and Pedrosa, F.O. (2010) Inoculation with Selected Strains of Azospirillum brasilense and A. lipoferum Improves Yield of Maize and Wheat in Brazil. Plant and Soil, 331, 413-425. http://dx.doi.org/10.1007/s11104-009-0262-0

[5] Glick, B.R., Patten, C.L., Holguin, G. and Penrose, D.M. (1999) Biochemical and Genetic Mechanisms Used by Plant Growth Promoting Bacteria. Imperial College Press, London, 267 p.

[6] Vessey, J.K. (2003) Plant Growth Promoting Rhizobacteria as Biofertilizers. Plant and Soil, 255, 571-586. http://dx.doi.org/10.1023/A:1026037216893

[7] Aguado, S.A. (2012) Uso de microorganismos como biofertilizantes. In: Aguado, S.A., Ed., Introducción al Uso y Manejo de los Biofertilizantes en la Agricultura, INIFAP/SAGARPA, Mexico, 35-78.

[8] Vosátka, M., Albrechtová, J. and Patten, R. (2008) The International Market Development for Mycorrhizal Technology. Mycorrhiza, 15, 419-438.

[9] Montero, L., Duarte, C., Cun, R., Cabrera, J.A. and González, P.J. (2010) Efectividad de biofertilizantes micorrízicos en el rendimiento de pimiento (Capsicum annuum) cultivado en diferentes condiciones de humedad del sustrato. Cultivos Tropicales, 31, 11-14. http://www.redalyc.org/articulo.oa?id=193217921002

[10] Klironomos, J.N. (2003) Variation in Plant Response to Native and Exotic Arbuscular Mycorrhizal Fungi. Ecology, 84, 2292-2301. http://dx.doi.org/10.1890/02-0413

[11] Plenchette, C., Clermont-Dauphin, C., Meynard, J.M. and Fortin, J.A. (2005) Managing Arbuscular Mycorrhizal Fungi in Cropping Systems. Canadian Journal of Plant Science, 85, 31-40. http://pubs.aic.ca/doi/pdf/10.4141/P03-159 http://dx.doi.org/10.4141/P03-159

[12] Tchabi, A., Coyne, D., Hountondji, F., Lawouin, L., Wiemken, A. and Oehl, F. (2010) Efficacy of Indigenous Arbuscular Mucorrhizal Fungi for Promoting White Yam (Dioscorea rotundata) Growth in West Africa. Applied Soil Ecology, 45, 92-100. http://www.sciencedirect.com/science/article/pii/S0929139310000302 http://dx.doi.org/10.1016/j.apsoil.2010.03.001

[13] Montes, G.N., Salinas, G.J., González, J.A., Loredo, P.R. and Díaz, P.G. (2010) Guía técnica de producción de sorgo dulce [Sorghum bicolor (L.) Moench] en Tamaulipas. Folleto Técnico No. 49. Campo Experimental Rio Bravo, INIFAP, Mexico, 35 p.

[14] Lemus, R. and Parrish, D.J. (2009) Herbaceous Crops with Potential for Biofuel Production in the USA. CABI Reviews: Perspectives in Agriculture, Veterinary Science, Nutrition and Natural Resources, 4, 1-23. http://citeseerx.ist.psu.edu/viewdoc/download?doi=10.1.1.169.8094\&rep=rep1\&type=pdf http://dx.doi.org/10.1079/pavsnnr20094057

[15] Calviño, M. and Messing, J. (2012) Sweet Sorghum as a Model System for Bioenergy Crops. Current Opinion in Biotechnology, 23, 323-329. http://dx.doi.org/10.1016/j.copbio.2011.12.002

[16] Ratnavathi, C.V., Kalyana, S., Komala, V.V., Chavan, U.D. and Patil, J.V. (2011) Sweet Sorghum as Feedstock for Biofuel Production: A Review. Sugar Tech, 13, 399-407. http://dx.doi.org/10.1007/s12355-011-0112-2

[17] Almodares, A and Hadi, M.R. (2009) Production of Bioethanol from Sweet Sorghum: A Review. African Journal of 
Agricultural Research, 4, 772-780.

http://www.academicjournals.org/article/article1380976619_Almodares\%20and\%20Hadi.pdf

[18] Prasad, S., Singh, A. Jain, N. and Joshi, H.C. (2007) Ethanol Production from Sweet Sorghum Syrup for Utilization as Automotive Fuel in India. Energy Fuels, 21, 2415-2420. http://dx.doi.org/10.1021/ef060328z

[19] Plenecassange, A., Romero, F.E. and López, B.C. (1999) Manual de laboratorio para análisis de suelo, planta y agua. INIFAP-ORSTOM, Gomez Palacio, Dro., Mexico, 279 p.

[20] Aguado, S.A. and Moreno, G.B. (2012) Biofertilizantes desarrollados por el INIFAP. In: Aguado, S.A., Ed., Introducción al Uso y Manejo de los Biofertilizantes en la Agricultura, INIFAP/SAGARPA, Mexico, 151-170.

[21] Bécquer, G.C., Prévost, D., Juge, C., Gauvin, C. and Delaney, S. (2012) Efecto de la inoculación con bacterias rizosféricas en dos variedades de trigo. Fase I: Condiciones controladas. Revista Mexicana de Ciencias Agrícolas, 3, 973-984.

[22] Matiru, V. and Dakora, F. (2004) Potential Use of Rhizobial Bacteria as Promoters of Plant Growth for Increased Yield in Landraces of African Cereal Crops. African Journal of Biotechnology, 3, 1-7. http://dx.doi.org/10.5897/AJB2004.000-2002

[23] Lopes, V.R., Bespalhok-Filho, J.C., Araujo, L.M., Vieira, F., Daros, E. and Oliveira, R.A. (2012) The Selection of Sugarcane Families That Display Better Associations with Plant Growth Promoting Rhizobacteria. Journal of Agronomy, 11, 43-52. http://dx.doi.org/10.3923/ja.2012.43.52

[24] Boucher, A., Dalpé, Y. and Charest, C. (1999) Effect of Arbuscular Mycorrhizal Colonization of Four Species of Glomus on Physiological Responses of Maize. Journal of Plant Nutrition, 22, 783-797. http://dx.doi.org/10.1080/01904169909365671

[25] Ilyas, N. and Bano, A. (2010) Azospirillum Strains Isolated from Roots and Rhizosphere Soil of Wheat (Triticum aestivum L.) Grown under Different Soil Moisture Conditions. Biology and Fertility of Soils, 46, 393-406. http://dx.doi.org/10.1007/s00374-009-0438-z

[26] Mehraban, A., Vazan, S., Narovi, M. and Ardakany, A. (2009) Effect of Vesicular-Arbuscular Mycorrhiza on Yield of Sorghum Cultivars. Journal of Food, Agriculture \& Environment, 7, 461-463.

http://world-food.net/download/journals/2009-issue_3_4/49.pdf 